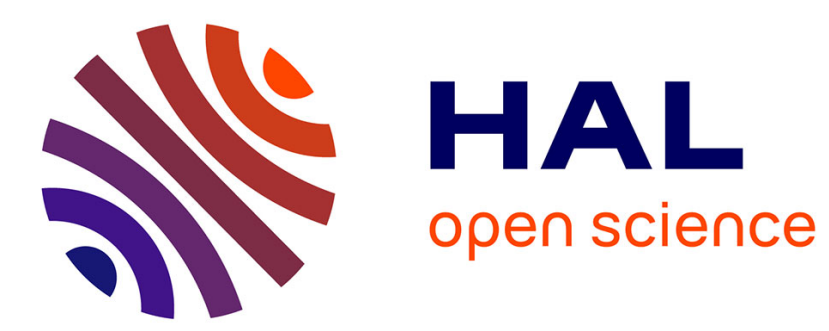

\title{
Paleomagnetic evidence for Neogene rotational deformations in the Aegean domain
}

C. Kissel, C. Laj, A. Poisson, Y. Savaşçin, K. Simeakis, J. Mercier

\section{To cite this version:}

C. Kissel, C. Laj, A. Poisson, Y. Savaşçin, K. Simeakis, et al.. Paleomagnetic evidence for Neogene rotational deformations in the Aegean domain. Tectonics, 1986, 5 (5), pp.783-795. 10.1029/TC005i005p00783 . hal-03540871

\section{HAL Id: hal-03540871 \\ https://hal.science/hal-03540871}

Submitted on 24 Jan 2022

HAL is a multi-disciplinary open access archive for the deposit and dissemination of scientific research documents, whether they are published or not. The documents may come from teaching and research institutions in France or abroad, or from public or private research centers.
L'archive ouverte pluridisciplinaire HAL, est destinée au dépôt et à la diffusion de documents scientifiques de niveau recherche, publiés ou non, émanant des établissements d'enseignement et de recherche français ou étrangers, des laboratoires publics ou privés. 
PALEOMAGNETTC EVIDENCE FOR NEOGENE ROTATIONAL DEFORMATIONS IN THE AEGEAN DOMAIN

C. Kissel, C. Laj, A. Poisşon, Y. Savaşçin, ${ }^{3}$ K. Simeakis, J. L. Mercier?

Abstract. New paleomapnetic data are reported from the islands of Skyros and Lesbos in Central Aegea and the Izmir-Foca region in Westem Anatolia. Together with previous resul ts obtained in Northwestern Greece and with results from Northern Aegea reported by others authors, these data suggest that the Lower Miocene arc was almost rectilinear, trending $E-W$ and that the curvature was acquired by opposed rotational deformations at each termination. Moreover, the observed inclinations, which are shallower than those expected on the basis of a geocentered dipole field, suggest a lange northward drift since Middle Miocene.

\section{INIRODUCTION}

During the last $10-15$ years many geological and geophysical investigations have been dedicated to the

1 Centre des Faibles Radioactivités, Laboratoire mixte ONRS-CEA, Domaine du CNRS, Gif-sur-Yvette, France.

2 Département des Sciences de la Terre, UA 730 Géophysique et Géodynamique interne, Université Paris $X I$, Orsay, France.

3 Dokuz Eylul Üniversitesi, Mịnendislik Mimmarlik Fakül tesi, Jeoloji Bolimü, Bomova, Izmir, Turkey.

4 Institute of Geological and Mining Research, Athens, Greece.

Copyright 1986

by the American Geophysical Union.

Paper number 670095 .

$0278-7407 / 86 / 006 \mathrm{~T}-0095 \$ 10.00$ study of the Tertiary geodynamical evolution of the Aegean region. Succeeding in time to the closure of the Tethyan troughs, this period is marked by the development of the Alpine belt and of the present-day structures.

Most of the recently presented geodynamical reconstructions assume that the Aegean domain is an Apulo-Anatolian microplate, accreted to Eurasia since Upper Cretaceous, which has undergone large scale defomations as a result of the Eurasia-Africa collision (Biju-Duval et al., 1977; Channell et al., 1979; Sengor and Yilmaz, 1981; Vergely, 1984; Dercourt et al., 1986). The relative movement of these two major plates has been described using the marine magnetic anomalies in the Atlantic and Indian oceans (Pitman and Talwani, 1972; Patriat et al., 1982; 0livet et al., 1982). But the extent of deformation of Aegea is such that only regional studies can give a reasonable account of its tectonic evolition.

For the Cenozoic, geological studies have documented the existence of an arcuate structure (Ionian-Lycian arc) (Mercier et al., 1979) which resulted from a very large compression and consequent shortening between Focene and Middle Miocene (Brumn, 1956; Aubouin, 1959; Institut de Géologie et Recherche du Sous-sol - Institut Français du Pétrole, 1966). The front of the Pindos overthrust and of the Ionian Zone slicing in Northwestem Greece and the front of the Lycian nappes onto the Pey Dağlari in Southwestem Anatolia are the clearest evidence of the two terminations of this arc (Figure 1). The present compressive front (Hellenic or Aegean arc) most probably appeared in the Lower Pliocene with a sudden "jump" from the Miocene arc position (Mercier et al., 1979). 


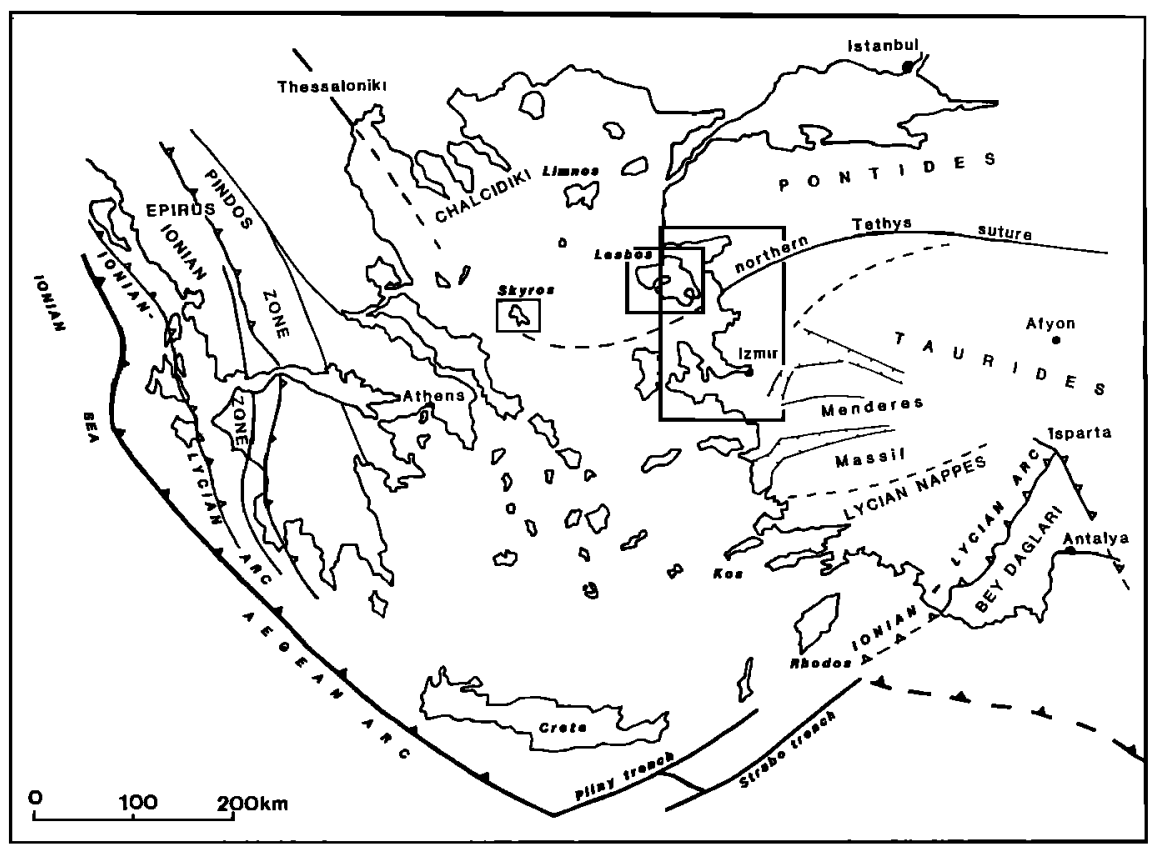

Fig. 1. Present day configuration of the Aegean domain showing the location of the front of the present day Aegean arc and the front of the Miocene arc (Ionian-Lycian arc).

Recent paleomagnetic results indicate that the entire region of Northwestem Greece has undergone a $45^{\circ}$ clockwise rotation which has occurred in two phases of comparable amplitude, one during Middle Miocene and one during Pliocene and Quaternary (Horner and Freenan, 1983; Kissel et al., 1984, 1985). Using these data, a palinspastic reconstruction shows that the Lower Miocene regional trend was almost $\mathrm{E}-\mathrm{W}$ in Northwestern Greece when the Ionian structures were formed. At the other termination of the arc, in Western Anatolia, the presence of windows yielded evidence of a progressive increase of the southward displacement of the nappes when moving southwestward from Isparta to the coast (Poisson, 1984). This suggests an apparent anticlockwise rotation, in contradiction with published paleomagnetic results from Western Anatolia (Kondopoulou and Lauer, 1984). However, these results cover a limited geographical area and probably reflect local rotation on a scale smaller than that of this study.

Although some paleomagnetic results from Central Aegea have recently been reported (Kondopoulou, 1985), clearly there is a need for additional data from postcollisional formations situated in this region and Western Anatolia.

This paper reports new results from 32 sites in the islands of Skyros and Lesbos and in the Izmir region. Together with the results from Northwestern Greece and from Northern Aegea reported by other authors, these results allow some tentative conclusions about the geodynamics of this region.

\section{GEOLOGICAL SETTING AND SAMPLING}

Al though compressional events have been documented in the Upper Miocene and Farly Quatemary, the tectonic evolution of Central Aegea has been doninated by an extensional regime since at least the Middle Miocene (Mercier et al;, 1979; Le Pichon and Angelier, 1979, 1982). This has resulted in large-scale nomal faulting, large Miocene grabens and extensional troughs of much greater extent than the compressional structures.

The entire area is largely affected by calc-alkaline volcanism of both Tertiary and Quatemary age. While the most recent products are found in the Southem Aegean sector, older volcanics of oligo-Miocene age are widespread all over the Central and Northern Aegean regions and in lestern Anatolia (Borsi et al;, 1972; Bellon et al., 1979; Innocenti et al., 1981; Fytikas et al., 1984). The older volcanic phase is considered to have been accomplished about 12-10 m.y. ago, while the first Plio-Quatemary products were erupted around $3 \mathrm{~m} . \mathrm{y}$. ago along the South Aegean arc. This time gap between the two cycles and a southward migration of the volcanic front has led different authors (Vilminot and Roberts, 1974; Fytikas et al., 1976, 1984; Bellon et al., 1979) to suggest that the two volcanic cycles might be attributed to two distinct geotectonic events.

Sedimentary formations in the studied area are essentially represented by continental (fluviolacustrine) and brackish limestones and marls 
which indicate the quasi-definitive emersion of these regions. In Western Anatolia, as a result of the main volcanic activity, widespread volcanosedimentary deposits are also present.

The results from Central Aegea reported here concern mainly volcanic formations in the islands of Skyros and Lesbos and the Izmir-Foça Region in Western Anatolia. In some cases interbedred sediments yielded a precise bedding correction, in some others a local structural study gave a reasonable estimate of it. Finally, in others no precise correction for tilting was possible and we had to rely on a subjective choice of "almost horizontal" lava flows based on the morphology of the flow itself.

Skyros

Five sites were sampled in the lava flows and volcanic domes located near the village of Bares, and showing calcalkaline characters. The products range between andesites and dacites. Their $\mathrm{K} / \mathrm{Ar}$ age is 15 m.y. (Fytikas et al., 1980), and they have been enupted through the mesozoic carbonates which appear more or less horizontal over this region.

Lesbos

Thirty-one sites were sampled in the different lithologic units of the islands (Figure 2). These include ignimbrites of rhyodacitic composition, lava flows from the Lower and Upper Lava Units, dykes and sedimentary formations of continental origin (limestones and marls). The lava flows are essentially composed of latitemandesite and dacite. The $\mathrm{K} / \mathrm{Ar}$ ages of the volcanic formations given by Borsi et al. (1972) range fron $16.2 \mathrm{m.y.}$ (dykes) to 18.0 m.y. (lava flows).

Izmi r-Foça Region

The locations of the sampled sites in this region are shown in the schematic map of Figure 3. It can be seen from this figure that the Neogene tectonic evolution has created a network of nomal faults separating a system of grabens and horsts. Moreover the entire region is situated on the Northern Tethyan suture zone (Izmir-Ankara Zone of Brinkman (1976)), i.e., on deep tectonic features which might have been reactivated during the Neogene. Tuffs and lacustrine marly limestones were sampled but most of the sites from this region were obtained from lava flows which show a trend from latite-andesites to dacites and rhyodacites. Some of them have been dated by Borsi et al. (1972) using the $\mathrm{K} / \mathrm{Ar}$ method and their ages range between 15 and 18.5 m.y. Basaltic rocks with alkaline affinity resulting from a younger volcanic activity (about $11 \mathrm{m.y}$.) are also present in the Urla and the Foca regions (Borsi et al., 1972). For the other flows no precise $\mathrm{K} / \mathrm{Ar}$ date is available as yet. However, Borsi et al. (1972) have shown that all the volcanic activity in this region is essentially of Middle Miocene age. In spite of its rather loose limits this age deternination is sufficient in the present state of advancement of the paleomapnetic study.

\section{RESULTS}

Both stepwise thermal and $\mathrm{AF}$ demagnetization were used (up to at least $550^{\circ}$ and $0.08 \mathrm{~T}$, respectively). When both methods isolated a stable component of magnetization, its direction was identical for samples from the same core. In many cases, however, AF demagnetization did not succeed in decreasing the renanent magnetization to values lower that $10-15 \%$ of the NRM, mostly because of the limited range of our demagnetizer which could be safely used without inducing an ARM. Thermal demagnetization gave in general more satisfactory results.

Measurements were done using a spinner magnetometer for the volcanic samples and a LETT 3-axes cryogenic magnetometer for the sedimentary ones.

In almost all cases a single stable component of magnetization was isolated after the first steps of demagnetization and its direction easily determined within $2^{\circ}-3^{\circ}$. Some of the demagnetization diagrams are shown in Figure 4.

Results from the different regions are reported separately.

Skyros

The five sampled sites have been studied using thennal demagnetization. From the results shown in Table $I$ and in Figure 5 it can be seen that the within-site scatter is small with the precision parameter $\mathrm{K}$ always greater than 20 , but that the mean direction of the stable magnetization obtained from site sk 231 is quite significantly different from the others. In contrast to the other sites which have been sampled in the bottom of the valley, this site is situated on the flank of a hill. A possible explanation of the different direction of magnetization could then be the presence of a local landslide which could easily be unnoticed because of the rather thick vegetation.

The mean direction given in Table 4 has been calculated taking into account the four coherent sites only. This direction shows that Skyros has undergone about $26^{\circ}$ of clockwise rotation since Middle Miocene.

Lesbos

The different formations which have been sampled in Lesbos have quite different lithologies and consequently widely different magnetic properties. Not all of these formations were found to be convenient for a paleomagnetic study. 


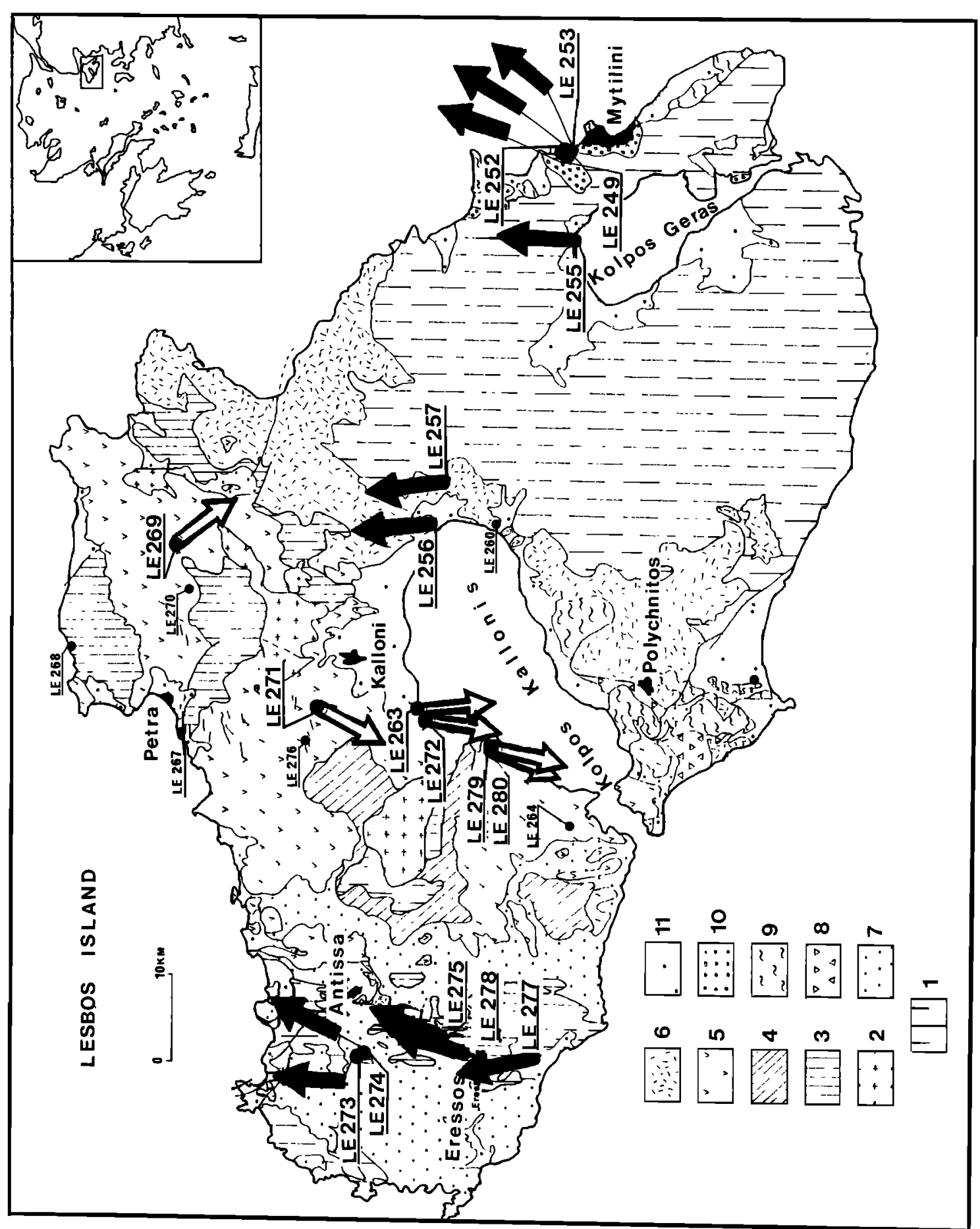




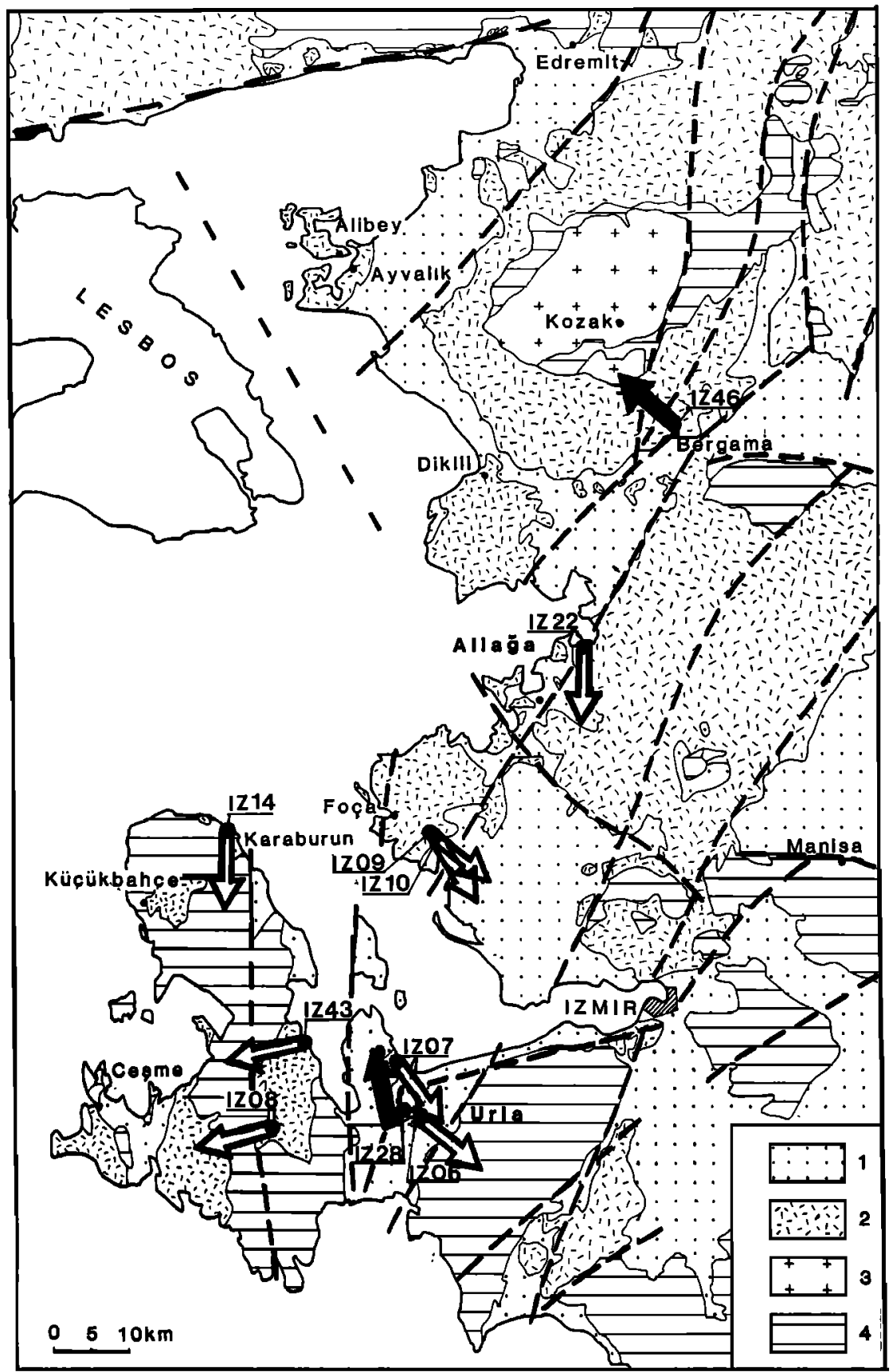

Fig. 3. The Iznir region. Simplified geological map of the sector between the Karaburun Peninsula and the Edremit gulf. (for locations, see Figure 1). 1, Neogene and Duaternary sedimentary fomations; 2, Neogen volcanics; 3, Granodiorite of Kozak; 4, Pre-Neogen basement. Interrupted lines indicate main fault directions. The arrows indicate the horizontal component of the paleomagnetic direction (white arrows: reverse sites; black arrows: nonnal sites).

First of all some of the sedimentary formations (the lacustrine limestones near the town of Mytilini) have a NRM lower that $0.0310^{-3} \mathrm{~A} / \mathrm{m}$ and were this not measurable with the necessary accuracy in spite of considerable care and the use of the double precision method of Vandenberg (1983) in connection with the cryogenic magnetometer.

In a general way the ignimbrite flows in Lesbos 

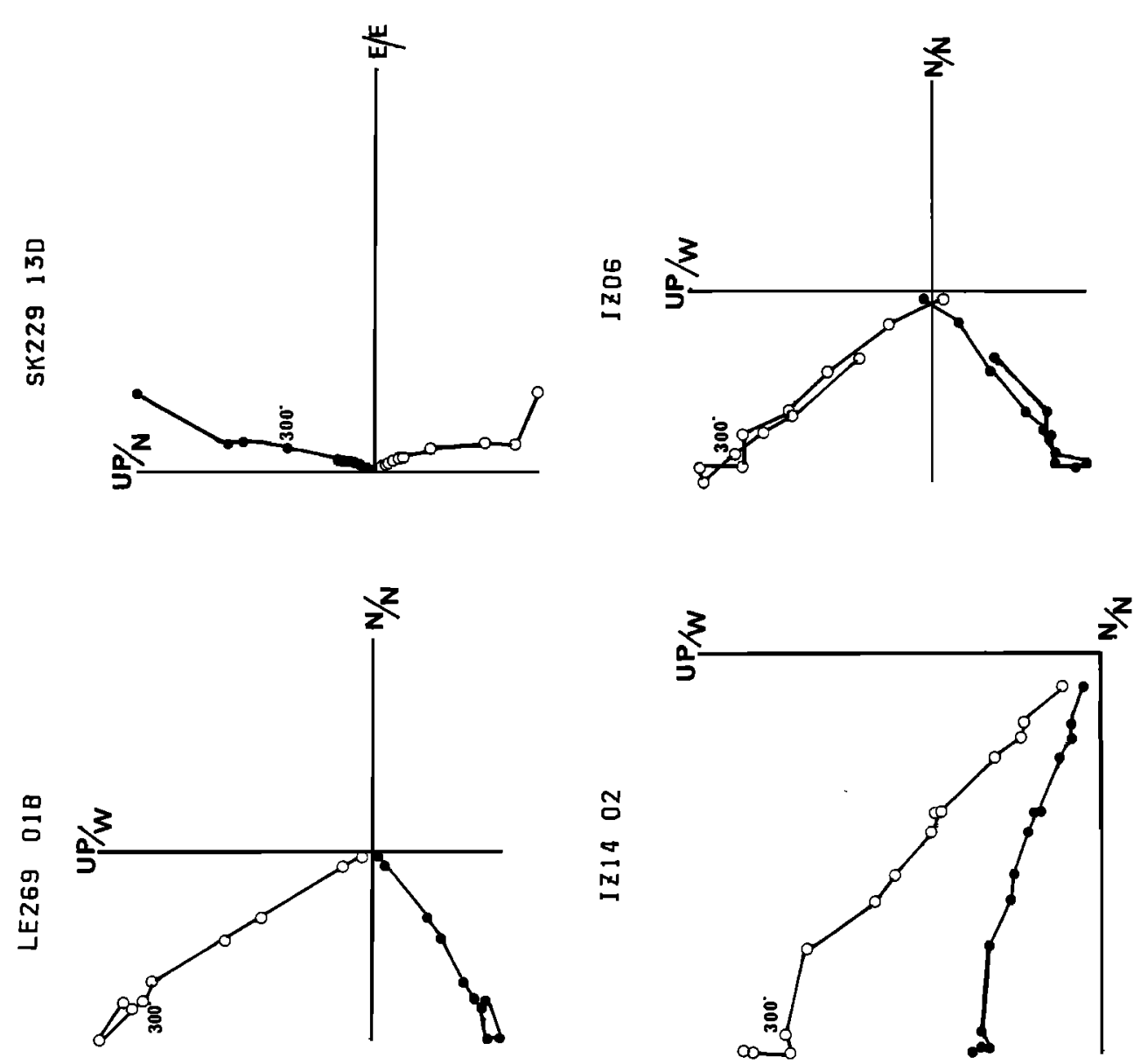

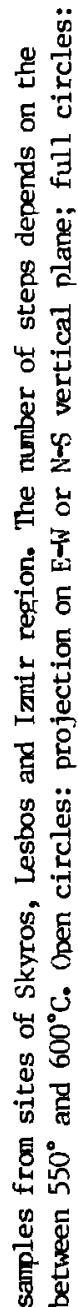
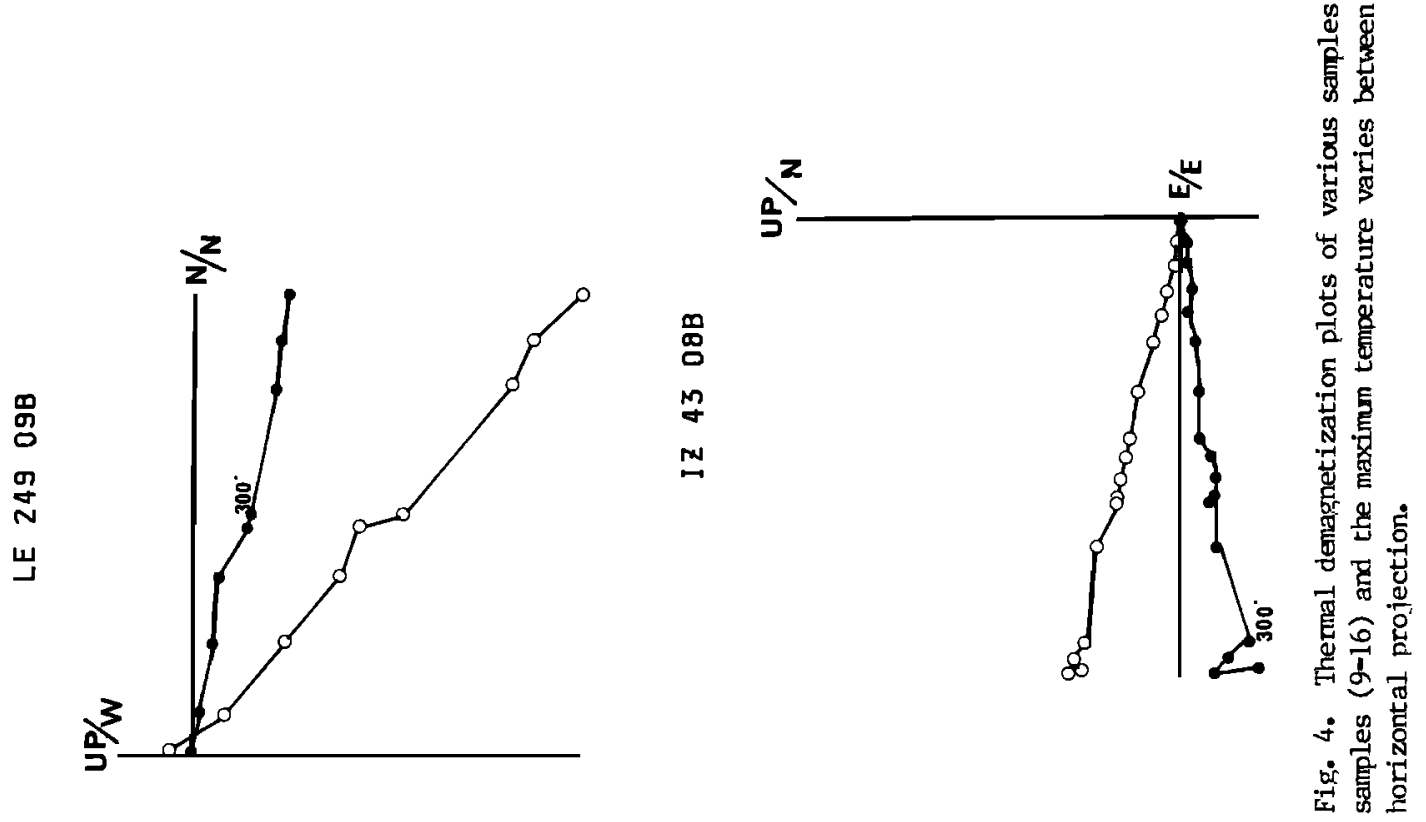
Table 1. Mean Paleomagnetic Directions Calculated Using Fisher's Statistic for Sites From Skyros Island

\begin{tabular}{lrrcrr}
\hline Sites & $N$ & {[} & $\mathrm{I}$ & $\mathrm{K}$ & $\boldsymbol{\alpha}_{95}$ \\
\hline SK 227 & 9 & 31.0 & 40.0 & 188 & 3.4 \\
SK 228 & 10 & 20.0 & 38.0 & 54 & 6.0 \\
SK 229 & 9 & 32.0 & 49.0 & 348 & 2.8 \\
SK 230 & 9 & 22.0 & 55.0 & 27 & 11.0 \\
SK 231 & 10 & 285.0 & 37.0 & 735 & 1.7 \\
\hline
\end{tabular}

No bedding correction has been applied on these sites.

cannot be considered as trustworthy material for a paleomagnetic study. Indeed, al though single samples are characterized by a perfectly rectilinear demagnetization plot, different sites sampled in the same flow at a distance of a few hundred meters gave, in some cases, sipnificantly different results. In one case (IE 260) the mean obtained inclination is so low that it would imply a totally unreasonable south-north displacement. this could perhaps be attributed to a large tectonic tilting, in spite of the almost horizontal appearance of the flow. Also in the case of the dykes the results were not as good as expected. Indeed, as for the ignimbrites, single samples have an almost perfect demagnetization diapram yielding a very precise paleomagnetic direction, but the within-site scatter is too high and $K$ is less than 15 in all cases.

The only sites which systematically gave coherent and reliable results were those in the lava flows from either the upper or the lower lava units. Only in one case did the demagnetization diagram not allow deternination of a stable paleomagnetic direction.

All the results are reported in Table 2, in the map of Fipure 2 and in Fioure 5. Only 17 out of the 27 studied sites can be considered as trustworthy for a paleomagnetic study. All the lava flows of the

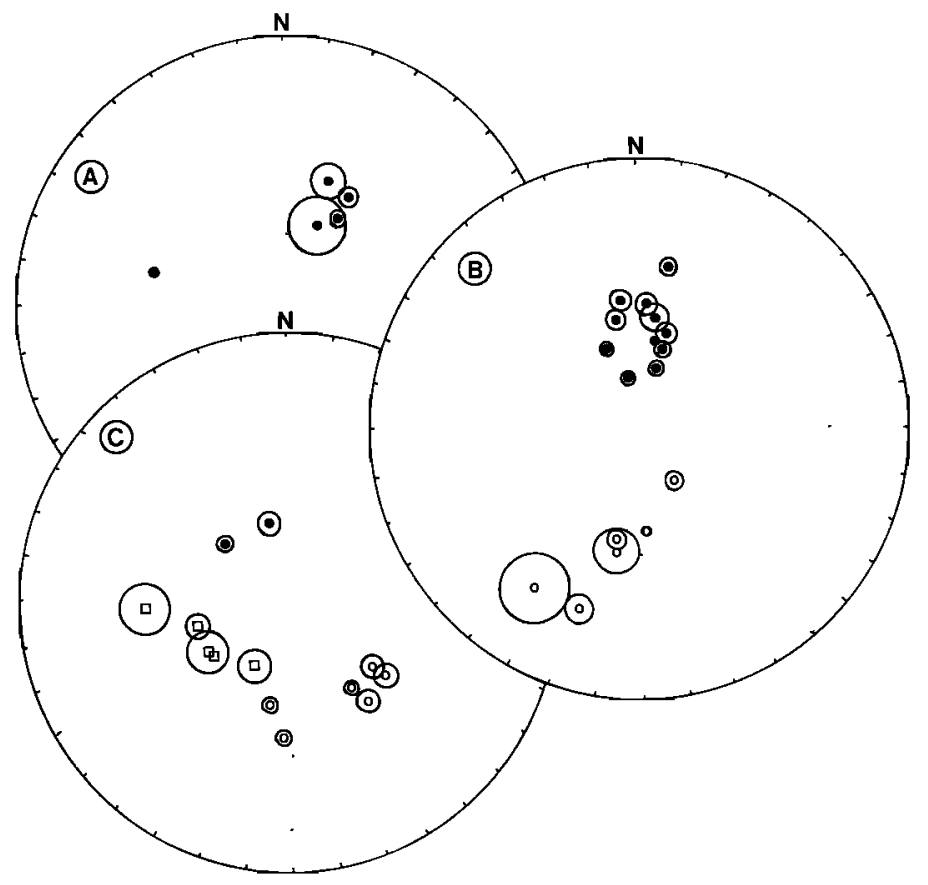

Fig. 5. Stereographic projection of the mean direction of each site and their angle of confidence from (A) Skyros, (B) Lesbos, and (C) the Izmir-Foca-Karaburun region. The sites which were not taken into account for the calculation of the final direction for Lesbos (see text) are not represented here. In the diagram (Figure 5C) the full and open circles are from the Izmir Foça region and are well opposed. The open squares correspond to the direction obtained on the Ceşme massif and are sippificantly different from the others. 
Table 2. Mean Paleomagnetic Direction of Each Measured Sites of Lesbos

\begin{tabular}{|c|c|c|c|c|c|c|c|c|}
\hline Sites & $\begin{array}{l}\text { Geological } \\
\text { formation }\end{array}$ & $\mathrm{N}$ & Dnb & Inb & $\mathrm{Db}$ & $\mathrm{Ib}$ & K & $\alpha_{95}$ \\
\hline LE $268^{a}$ & & 9 & & & rejected & & & \\
\hline LE 273 & & 10 & 31.4 & 58.5 & 19.0 & 56.0 & 247 & 2.6 \\
\hline LE 274 & lower & 10 & 358.6 & 44.3 & 353.5 & 38.7 & 134 & 3.8 \\
\hline LE 275 & lava & 9 & $\ldots$ & $\ldots$ & 17.3 & 64.0 & 233 & 3.0 \\
\hline LE 277 & unit & 9 & $\cdots$ & $\ldots$ & 349.5 & 45.6 & 170 & 3.5 \\
\hline LE 278 & & 9 & $\cdots$ & $\cdots$ & 10.0 & 44.6 & 72 & 5.0 \\
\hline $\begin{array}{l}\text { LE } 263 \\
\text { LE } 264^{a}\end{array}$ & & $\begin{array}{l}9 \\
8\end{array}$ & $\cdots$ & $\cdots$ & $\begin{array}{c}177.8 \\
\text { rejected }\end{array}$ & -49.5 & 1333 & 1.3 \\
\hline LE 269 & & 8 & $\ldots$ & ... & 146.0 & -63.6 & 177 & 3.7 \\
\hline LE 271 & upper & 11 & $\ldots$ & $\ldots$ & 214.0 & -35.0 & 15 & 10.0 \\
\hline LE 272 & lava & 10 & $\ldots$ & $\ldots$ & 191.7 & -44.7 & 181 & 3.3 \\
\hline LE 279 & unit & 7 & $\ldots$ & $\cdots$ & 199.4 & -20.0 & 144 & 4.4 \\
\hline LE 280 & & 7 & ... & $\cdots$ & 191.2 & -41.0 & 46 & 7.8 \\
\hline LE 256 & & 11 & $\ldots$ & $\ldots$ & 340.5 & 55.0 & 229 & 2.8 \\
\hline LE 257 & & 10 & $\ldots$ & $\ldots$ & 350.0 & 69.0 & 262 & 3.0 \\
\hline LE $260 \mathrm{I}^{\mathrm{a}}$ & ipnimbrites & 5 & 9.0 & 20.0 & 6.0 & 21.0 & 101 & 6.0 \\
\hline LE 260 II $^{a}$ & & 7 & 19.3 & 6.0 & 20.0 & 9.0 & 107 & 5.0 \\
\hline LE 260 III $^{a}$ & & 7 & 12.3 & 17.6 & 10.2 & 19.3 & 206 & 3.7 \\
\hline LE 260 IV $^{a}$ & & 9 & 8.3 & 12.7 & 6.0 & 14.0 & 190 & 3.3 \\
\hline $\mathrm{LEE} 267^{a}$ & & 11 & ... & $\ldots$ & 221.0 & -63.8 & 3 & 24.0 \\
\hline LE $270^{a}$ & dykes & 6 & $\ldots$ & $\ldots$ & 251.0 & 31.5 & 12 & 21.0 \\
\hline LE $276^{a}$ & & 11 & $\cdots$ & $\cdots$ & 59.7 & 43.5 & 2 & 35.0 \\
\hline LE 249 & Mytlilini & 10 & 8.0 & 37.0 & 8.0 & 37.0 & 280 & 2.6 \\
\hline LE 252 & & 8 & 0.2 & 49.0 & 0.0 & 49.0 & 154 & 4.0 \\
\hline LE 253 & basalts & 9 & 13.6 & 59.5 & 13.6 & 59.5 & 196 & 4.0 \\
\hline $\begin{array}{l}\text { LE } 255 \\
\text { LE } 258\end{array}$ & $\begin{array}{l}\text { limestones } \\
\text { marls }\end{array}$ & $\begin{array}{l}11 \\
11\end{array}$ & $\cdots$ & $\cdots$ & $\begin{array}{c}11.3 \\
\text { rejected }\end{array}$ & 53.3 & 704 & 1.6 \\
\hline
\end{tabular}

a Sites rejected on the basis of undeterminable direction or too large within-site scattering $(K<15)$. The four sites sampled in the same ignimbrite flow (LE $260 \mathrm{I}, \mathrm{II}, \mathrm{III}, \mathrm{IV}$ ) are also rejected because of their anomalous inclination. The directions are given before (Dnb, Inb) and after (Db, Ib) bedding correction except for the sites which do not present any tectonic bedding and whlch are reported only in $\mathrm{Db}$ and $\mathrm{Ib}$.

upper lava unit are of reverse polarity; this could surgest that they were emitted during a rather short eruptive phase.

When all the reverse directions are inverted through the origin the paleomagnetic direction obtained from the 17 reliable sites using Fishers statistics is

$\mathrm{N}=17 \quad \mathrm{D}=6^{\circ} \quad \mathrm{I}=49.5^{\circ} \quad \mathrm{K}=24.7 \quad \alpha_{95}=6.8^{\circ}$

This result can be compared with those previously obtained by other authors. Kondopoulou and Lauer (1984) have reported results from 10 sites and obtained the paleomagnetic direction:

$$
\mathrm{N}=10 \quad \mathrm{D}=12.5^{\circ} \quad \mathrm{I}=49^{\circ} \quad \mathrm{K}=11 \quad \alpha_{95^{\circ}}=15^{\circ}
$$$$
\text { Pe-Piper (1978) has presented results obtained }
$$

from 47 volcanic samples from different sites and obtained an average of

$n$ (samples) $=47 \quad \mathrm{D}=8.4^{\circ} \quad \mathrm{I}=40^{\circ} \quad \mathrm{K}=8 \quad \alpha_{95^{2}}=7.8^{\circ}$

The mean paleomagnetic direction obtained in this paper is thus not significantly different from that obtained by these authors. However the rather severe selection of suitable sites has led to a greater accuracy.

\section{Izmir-Foça Region}

Ten sites from this region have been completely studied. Eight of these are from lava flows, one from the lacustrine limestones near Urla and one from a 
Table 3. Mean Directions of Each Measured Site in the Izmir Region

\begin{tabular}{|c|c|c|c|c|c|c|c|c|}
\hline Sites & $\begin{array}{c}\text { Geographical } \\
\text { position }\end{array}$ & $\mathrm{n}$ & Dnb & Inb & $\mathrm{Db}$ & $\mathrm{Ib}$ & K & $\alpha_{95}$ \\
\hline IZ 09 & & 12 & 169.0 & -62.5 & 127.2 & -41.0 & 93 & 4.2 \\
\hline IZ 10 & & 8 & 125.5 & -20.5 & 144.0 & -47.5 & 500 & 2.2 \\
\hline IZ 22 & & 11 & ... & ... & 190.0 & -48.0 & 387 & 2.4 \\
\hline IZ 46 & Izmi $\mathrm{r}$-Foça & 8 & 319.5 & 53.8 & 314.0 & 53.8 & 540 & 2.3 \\
\hline IZ 06 & & 12 & $\ldots$ & $\ldots$ & 128.0 & -47.0 & 158 & 4.2 \\
\hline IZ 07 & Region & 8 & 144.0 & -34.0 & 141.0 & -39.5 & 249 & 3.3 \\
\hline IZ 14 & & 8 & 181.0 & -51.0 & 182.0 & -36.0 & 264 & 3.2 \\
\hline IZ 28 & & 8 & 346.0 & 54.0 & 349.6 & 57.0 & 57 & 4.0 \\
\hline I2 43 & & 8 & ... & $\cdots$ & 234.0 & -53.5 & 450 & 2.6 \\
\hline LZ 08 & Çeşme & 11 & $\ldots$ & $\ldots$ & 267.0 & -34.5 & 23 & 8.5 \\
\hline ÇeşmeI & massif & 7 & $\cdots$ & ... & 254.0 & -51.9 & 189 & 4.4 \\
\hline ÇeşmeII & & 7 & $\ldots$ & $\ldots$ & 237.0 & -51.5 & 52 & 8.4 \\
\hline ÇeşmeIII & & 5 & ... & $\cdots$ & 207.0 & -59.5 & 132 & 6.7 \\
\hline
\end{tabular}

No bedding corrections have been applied on the data of the "Çeșme massif." Results from Çeşme I, II and III are from Kondopoulou and Lauer (1984) (see text).

tuff formation near Foça which has most probably been reheated by an overlying lava flow. The results are reported in Table 3 and schematically in Figures 3 and 5.

It can be seen from this table that the results from the two sites located near Ceşme (IZ 08, 43) differ considerably from the others and seem to indicate a large clockwise rotation, virtually identical to the one reported by Kondopoulou and
Lauer (1984) (Ceşre I, II, III). Although the bedding plane of the Cesme massif is not orecisely known, its morphological and geological aspect indicates that it is never very large. Consequently any nossible error in the bedding plane (both Kondopoulou and Laver and ourselves have assumed an horizontal bedding) cannot introduce distortions of the results as large as the discrepancy observed between the Ceşme sites and the others. Most probably the different declination

Table 4. Mean Directions Obtained Using Fisher's Statistic on N Sites of Each Region by Different Authors

\begin{tabular}{|c|c|c|c|c|c|c|c|c|}
\hline Regions & Epoch & $\mathrm{N}$ & D & I & K & $\alpha_{95}$ & $\begin{array}{c}\text { Total } \\
\text { Rotation }\end{array}$ & References \\
\hline Crete & Upper Milocene & 21 & 358 & 46 & 47 & 4.4 & $0^{\circ}$ & 1 \\
\hline Rhodes & Pliocene & 5 & 1 & 47 & 85 & 6.7 & $0^{\circ}$ & 1 \\
\hline Ionian Islands & \multicolumn{8}{|c|}{ Pliomouaternary variable from $25^{\circ}$ to $0^{\circ}$ from $5 \mathrm{~m} \cdot \mathrm{y}$. to Present } \\
\hline $\begin{array}{l}\text { Epinus- } \\
\text { Akarnania }\end{array}$ & oligocene & 29 & 58 & 39 & 30 & 5.0 & $+45-50^{\circ}$ & 2 \\
\hline Chalkidiki & Eocene & 12 & 37 & 31 & 25 & 11.0 & $+37^{\circ}$ & 3 \\
\hline Skvros & & 4 & 26 & 45 & 82 & 7.7 & $+26^{\circ}$ & 4 \\
\hline Lesbos & Milocene & 17 & 6 & 49 & 25 & 6.8 & $+6^{\circ}$ & 4 \\
\hline Izmir Region & & 8 & 151 & -49 & 19 & 11.2 & $-29^{\circ}$ & 4 \\
\hline
\end{tabular}

The angle of total rotation is noted positive for clockwise rotation and negative for anticlockwise one. References: 1, Laj et al. (1982); 2, Kissel et al. (1985); 3, Kondopoulou (1985); 4, this paper. 

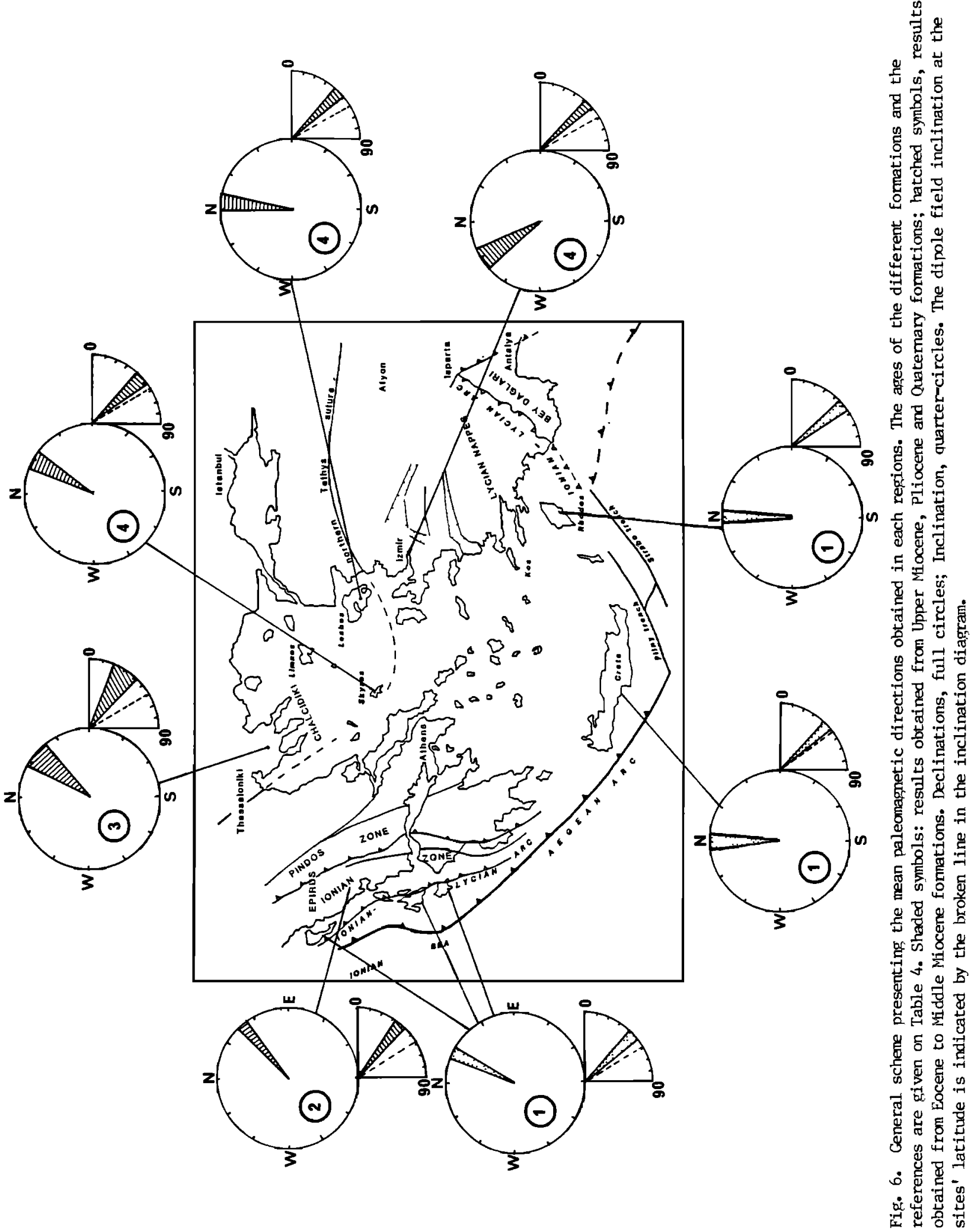
values indicate the presence of a local rotation. In our opinion the other sites, for which in addition we obtained precise bedding correction, are simnificant on a greater geographical scale. For this reason the regional mean paleomagnetic direction reported in Table 4 has been calculated by using the other eight sites.

\section{DISCISSION}

Together with previous paleomagnetic data already reported from the Aegean area, the present results yield a tentative picture of the Neogene rotational deformations of this region. All the results from the different geographical zones are reported in Table 4 and in a schenatic way on the map of Figure 6.

Although the lack of energed lands in Central Aegea does not allow an extensive sampling, it can be seen that the large clockwise rotation $\left(45^{\circ}-50^{\circ}\right)$ measured in Northwestern Greece progressively decreases when moving eastward. Indeed the Chalkidiki peninsula has rotated about $37^{\circ}$, Skyros about $25^{\circ}$ and the rotation of Lesbos is only $6^{\circ}$, which is barely significant. The sense of rotation then becomes anticlockwise with a rather change between Lesbos and westem Anatolia. This abrupt change is most probably related to the existence of an intense fault system which might also be responsible for the large scatter of the paleomagnetic data observed in this region. The main structural lines of this region resulted from a large scale extension roughly striking N-S which began during Lower to Middle Miocene and which created, mainly during Upper Miocene and Lower Pliocene, the system of $\mathrm{E}-\mathrm{W}$ and NNE-SSW grabens (Kaya, 1981; Sengòr et al., 1985). The scatter of the paleomagnetic results might then result from the relative rotations of the different small blocks created by the grabens system. Indeed, the tectonic activity has persisted throughout the Miocene, the Pliocene and Quatemary: a strike-slip motion of some of the numerous faults during recent periods would probably be most effective in causing relative rotations of the blocks. Although no detailed and extensive study of the Neogene faults in this region has been carried out yet, motions of this kind have been clearly demonstrated for the Buyuik Menderes faults (Dumont et al., 1981a, b; Angelier et al., 1981). If these considerations provide a reasonable geological explanation for the scatter, one has also to keep in mind that the data are quite scarse as yet, so that other explanations might arise when other data will be available.

Whatever the explanation for the scatter, when all the trustworthy sites are averaged by using Fisher's statistics, the mean result for the Izmir region is an anticlockwise rotation. ite are well aware that additional data are needed before this rotation can be firmly considered as significant for the entire Western Anatolia North of the Lycian nappes.

Nevertheless the present results yield a tentative description of the main rotational defonnations which have occurred in the Aegean domain during Neogene.

First, a palinspastic reconstruction in both Northwestem Greece and Western Anatolia shows that the orientation of the main structures was almost $E-W$ in both regions. This implies that the riocene arc was almost rectilinear at its formation and that the curvature has been acquired tectonically by opposed rotational deformation at both terminations. The data are however still too scarce to yield precise ideas about the mechanisis involved in these rotational deformations, such as rotation of sriall blocks or rigid-plastic defomation (McKenzie, 1972, 1978; Tapponnier, 1977; Dewey and Sengor, 1979; Mercier, 1979).

A second major point which can be noticed in the results from all the regions is that the measured values of the inclination angles are lower than expected on the basis of a geocentered dipole field $\left(59^{\circ}\right)$. This is observed in both our own and other authors' results (Figure 6) and in both sedimentary and volcanic fomations. Thus these results are a convincing evidence that a significant northward motion of Aegea has occurred during the last 15-20 $m_{\text {. }}$. The studied formations were situated about $10^{\circ}$ to the south of their present position. It is significant that a similar northward motion of Africa has been documented in a recent publication by Tarxe et al. (1983).

Aknowledements. The Director of the Institute of Geology and ifining Research (IGM) at Athens kindly provided the necessary pernits. The Earth Sciences group of the Dokuz Eylil iniversitesi has helped us in the field work. Alain Mazaud solved all the software problems in connection with the cryogenic magnetometer. Dario Decini and Sylvie Guitton helped with the sampling. The financial support was given bv the INAG-ATP Sismogénèse, Plis, Failles, Mécanique de la lithosphère. Contribution CFR 765.

\section{REFERENCES}

Angelier, J., J. Lumont, H. Karamanderesi, A. Poisson, S. Simsek, and S. Uysal, Analysis of fault mechanians and expansion of Southwest Anatolia since the Late Miocene, Tectonophysics, 75, Tl-T9, 1981.

Aubouin, J., Contribution à l'étude géologique de la Grèce septentrionale, les confins de l'Epire et de la Thessalie, Ann. Ceol. Pavs Hell., 10, 525pp, 1959.

Bellon, H., J. J. Jarrige, and D. Sorel, Les activités magmatiques égéennes de 1 'oligocène à nos jours, et leurs carres géodynamiques, données nouvelles et synthèse. Rev. Ceogr. Phys. Ceol. Dyn., 21, 41-55, 1979.

Bi ju-Duval, B., J. Dercourt, and X. Le Pichon, From the Tethys Ocean to the Mediterranean Seas: A plate tectonic model of the evolution of the Westerm 
Alpine system, in thistoire structurale des Bassins Méditerranéens, edited by B. Biju-Duval and L. Montadert, pp.143-164, Technip, Paris, 1977.

Borsi, S., G. Ferrara, F. Imocenti, and R. Mazzuoli, Geochronology and Petrology of recent Volcanics in the Eastern Aegean Sea (Western Anatolia and Lesbos island), Bull. Volcanol., XXXVI-3, 473-496, 1972.

Brinckman, R., Geology of Turkey, 158pp., Enke, Stuttgart, 1976.

Brunn, J. H., Etude géologique du Pinde septentrional et de la Macédoine occidentale, Ann. Geol. Pays Hell., \&, 258pp, 1956.

Channel1, J. E. T., B. D'argenio, and F. llorvath, Adria, the African Promontory in Mesozoic Wediterranean Palaeogeography, Earth Sci. Rev., 15, 213-292, 1979.

Dercourt, J., L. P. Zonenshain, L. E. Rícou, V. G. Kasmin, X. Le Pichon, A. L. Knipper, C. Grandjacquet, I. M. Sbortshikov, J. Ceyssant, C. Lepvrier, D. H. Pechersky, J. Boulin, J. C. Sibuet, L. A. Savostin, O. G. Sorokhtin, M. Westphal, M. L. Bazhenov, J. P. Lauer, and B. Biju-Duval, Geological evolution of the Tethys belt convengence zone from the Atlantic to the Pamir since the Lias, Tectonophysics, 123, 241-315, 1986.

Dewey, J. F., and A. M. C. Şengör, Aegean and surrounding regions: Complex multiplate and continum tectonics in a convergent zone, Geol. Soc. Am. Bull. , 90 I, 84-92, 1979.

Dumont, J. F., S. Uysal, and S. Simsek, Superposition des jeux sur une faille et succession des évènements néotectoniques: L'exemple $d$ 'Ephèse (Turquie), C. R. Somm. Soc. Geol. Fr., 1, 22 24, 1981a.

Dumont, J. F., S. lysal, S. Simsek, H. Karananderesi, and $\mathrm{J}$. Letousey, Formation of the grabens in Southwestern Anatolia, Bull. Min. Res. Explor. Inst. Turkey 1979, 92, 7-18, 1981b.

Fytikas, M., O. Giuliani, F. Innocenti, G. Marinelli, and R. Mazzuoli, Ceochronological data on recent magmatism of the Aegean Sea, Tectonophysics, 31, 29-34, 1976.

Fytikas, M., O. Giuliani, F. Innocenti, P. Manetti, R. Wazzuoli, A. Peccerillo, and L. Villari, Neogene volcanism of the Northem and Central Aegean region, Ann. Ceol. Pays Hell., 30, 106-129, 1980.

Fytikas, M. , F. Imocenti, P. Manetti, R. Mazzuoli, A. Peccerillo, and L. Villari, Tertiary to Quatemary evolution of volcanism in the Aegean regrion, The Geological Evolution of the Eastern Mediterranean, Spec. Publ. Ceol. Soc. London, 17, 687-700, 1984.

lorner, F., and R. Freeman, Paleomagnetic evidence from pelagic limestones for clockwise rotation of the Ionian Zone, Western Greece, Tectonophysics, 98, 11-27, 1983.

Institut de Géologie et Recherche du Sous-sol Institut Francais du Pétrole, Etude géologique de 1 'Epire (Grèce nord-occidentale), 306pp., Ed. Technip, Paris, 1966.
Innocenti, F., P. Manetti, R. Mazzuoli, G. Pasquare, and L. Villari, Neogene and Quatemary volcanism in the Eastern Mediterranean. Time-space distribution and geotectonic implication, in Sedimentary Basins of itediterranean Margins, Italian project of Oceanography, edited by C. Wezel, pp. 369-385, Technoprint, Bologna, 1981.

Kaya, 0. , Miocene reference section for the coastal parts of West-Anatolia, Newslett. Stratigr., 10, 164-191, 1981.

Kissel, C., \%. Jamet, and C. Laj, Palaeomagnetic evidence of Miocene and Pliocene rotational deformations of the Aegean Area, The Ceological Evolution of the Eastern Mediterranean, Spec. Publ. Geol. Soc. London, 17, 669-679, 1984.

Kissel, C., C. Laj, and C. Huller, Tertiary geodynamical evolution of Northwestern Greece: Paleonagnetic results, Earth Planet. Sci. Lett., 72, 190-204, 1985.

Kondopoulou, D., Paleomagnetic study of the Tertiary intrusives from Chalkidiki (Northem Greece), (Abstract), Terra Cognita, 5, 265, 1985.

Kondopoulou, D., and J. P. Lauer, Palaeomagnetic data on the Northern part and a tentative overview on Neogene rotations in the Aegean zone, The Geological Evolution of the Eastern Mediterranean, Spec. Pub1. Ceol. Soc. London, 17, 681-686, 1984.

Laj, C. , Mi. Jamet, D. Sorel, and J. P. Valente, First paleonagnetic results from Mio-Pliocene series of the Hellenic sedimentary arc, Ceodynamics of the Hellenic Arc and Trench, Tectonophysics, 86, 45-67, 1982.

Le Pichon, X., and J. Angelier, The Hellenic Arc and Trench system: A key to the neotectonic evolution of the Eastern Mediterranean area, Tectonophysics, 60, $1-42,1979$.

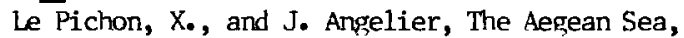
Philos. Trans. R. Soc. London A, 300, 357-372, 1982.

McKenzie, D., Active tectonics of the Mediterranean Region, Geophys. J. R. Astron. Soc., 30, 109-185, 1972.

MeKenzie, D., Active tectonics of the Alpide-Himalayan belt: the Aegean Sea and surrounding regions, Geophys. J. R. Astron. Soc., $55,217-254,1978$.

Mercier, J. L., Sipnification néotectonique de 1'Arc Eggéen: Une revue des idées, Rev. Ceol. Dyn. Ceogr. Phys., 21, 5-15, 1979.

Mercier, J. L., M. Delibassis, A. Gauthier, J. J. Jarrige, F. Lemeille, H. Philip, M. Sébrier, and D. Sorel, La néotectonique de 1 'Arc Egéen, Rev. Ceol. Dyn. Ceogr. Phys., 21, 61-72, 1979.

Olivet, J. L., J. Bonnin, P. Beuzart, and J. M. Auzende, Cinématique des plaques et Daléogéographie: Une revue, Bull. Soc. Geol. Fr., 24 (7), parts 5-6, 875-892, 1982.

Patriat, P., J. Segoulin, R. Schlich, J. Coslin, J. M. Auzende, P. Beuzart, J. Bonnin, and J. L. Olivet, Les mouvenents relatifs de l'Inde, de 
1'Afrique et de 1'Eurasie, Bull. Soc. Ceol. Fr., 24 (7), part 2, 363-373, 1982.

Pe-Piper, C. G., The Cenozoic volcanis rocks of Lesbos island (in greek), D. Sc. thesis, 379pp., Univ. of Patras, Greece, 1978.

Pitman, W. C., and $Y_{0}$ Talwani, Sea-floor spreading in the North Atlantic, Ceol. Soc. Am. Bull., 83, $619-649,1972$.

Poisson, A., The extension of the Ionian trough into Southwestern Turkey, The Ceological Evolution of Eastern Mediterranean, Spec. Publ. Ceol. Soc. London, 17, 241-250, 1984.

Şengör, A. M. C., and Y. Yilnaz, Tethian evolution of Turkey: A plate tectonic approach, Tectonophysics, 75, 181-242, 1981.

Şengör, A. M. C., N. Gorur, and F. Saroglu, Strike-slip faulting and related basin formation in zones of tectonic escape. Turkey as a case of study, Spec. Publ. Soc. Econ. Paleont. Mineral., in press, 1986.

Tapponnier, P., Evolution tectonique du système alpin en Mediterranée: Poinconnement et écrasement rigide-plastique, Bull. Soc. Ceol. Fr., XIX-3, 437-460, 1977.

Tauxe, L., J. Besse and J. L. Labrecque, Paleolatitudes from DSDP Leg 73 sediments cores implications for the apparent polar wander path for Africa during the late Mesozoic and Cenozoic, Geophys. J. R. Astron. Soc., 73, 315-324, 1983.

Vandenberg, J., Reappraisal of paleomagnetic data from Gargano (South Italy), Tectonophysics, 98, $29-41,1983$.

Vergely, P., Tectonique des ophiolites dans les Hellénides internes (déformations, métamorphismes et phénomènes sédimentaires). Conséquences sur 1 'évolution des répions téthysiennes occidentales, thèse d'état, $41 \mathrm{lpp}$, , Lniv. d'Orsay, Orsay, France, 1984.

Vilminot, J. C., and U. Roberts, A propos des relations entre le volcanisme et la tectonique en Mer Egée, C. R. Acad. Sci. Paris, 278, 2099-2102, 1974.

C. Kissel and C. Laj, Centre des Faibles Radioactivités, Laboratoire mixte CNRS-CEA, Domaine du CNRS, 91190 Gif-sur-Yvette, France.

J. L. Mercier and A. Poisson, Département des Sciences de la Terre, UA 730 Céophysique et Géodynamique Interne, Université Paris XI, 91405 Orsay Cedex, France.

Y. Savaşçin, Dokuz Eylül Üniversitesi, Mïhendislik Mimarlik Fakültesi, Jeoloji Bölümü, Bomova, Izmir, Turkey.

K. Simeakis, Institute of Ceological and Mining Research, 70 Messoghion Street, Athens, Greece.

(Received May 15, 1985;

revised December 20, 1985;

accepted February 3, 1986) 